\title{
Essay on Decolonial Aesthetics in Latin America ${ }^{1}$
}

\author{
Ensaio sobre estéticas descoloniais em América Latina
}

Ensayo sobre estéticas decoloniales en América Latina

\author{
Paula Cristina Pomarico Luciano
}

\begin{abstract}
This essay aims to trace an overview of the decolonial aesthetics through the analysis of artistic expressions that occurred in Latin American territory. This analysis will allow us to enhance the cultural and artistic practices within its plurality and the typical spatial archetypes within its temporal resignification. The necessity of creation and the search for new epistemological fields translate the historical movements of the Latin-American cultural mouvance and the juxtaposition of temporalities, practices and the confluence of knowledge. We can find a stage of resistance and socio-historical borders subverted, mainly in the context of artistic and cultural manifestations and its capacity of invention and relativization. This essay aims to bring a reflection on the construction of cultural spaces and the dismantling of a single hegemonic perspective to define the artistic practices. The analysis and the epistemological questioning of the Latin-American trans-historical movement delineates an overview of the history of artistic productions that came out of practices and every-day life inventions and the elaboration of temporary spaces of claim and contestation through exhibitions, performances, festivals, and so forth. The idea of subverting a geopolitical imaginary and a cartography of the world (even if initially in local dynamics) consists of a central focus of this work.
\end{abstract}

Keywords: Epistemological Fields; Decoloniality; Space and Temporalities; Decolonial Aesthetics; Cultural Mouvance

\section{Resumo}

Esse ensaio tem como estrutura traçar um panorama das estéticas descoloniais através da análise das expressões artísticas que tiveram como palco o território latino-americano. Essa análise nos permitirá de evidenciar as expressões e práticas culturais dentro da sua pluralidade e os arquétipos espaciais típicos dentro da sua ressignificação temporal. A necessidade de criação e busca por novos campos epistemológicos traduzem o movimento histórico das movências culturais latino-americanas e a justaposição de temporalidades, práticas e a confluência de conhecimentos. Podemos encontrar um cenário de resistência e de fronteiras sócio-históricas subvertidas, principalmente no que se refere à realização de manifestações artísticas e culturais e a sua capacidade de invenção e relativização. Esse ensaio tem por objetivos trazer uma reflexão sobre a construção de espaços culturais e a desconstrução de um olhar único e dominante para definir as práticas artísticas. A análise e o questionamento epistemológico do movimento trans-histórico latino-americano desenha um panorama da história das produções artísticas provenientes de práticas e invenções do quotidiano e da elaboração de espaços temporários de reivindicação e contestação a partir de exposições, performances, festivais, etc. A ideia de subverter um imaginário geopolítico e uma ordem cartográfica do mundo (mesmo que inicialmente a partir de dinâmicas locais) consiste em um ponto central desse trabalho.

\footnotetext{
${ }^{1}$ Artigo apresentado no Simpósio Temático (FRONTEIRAS CULTURAIS EM CONTEXTOS EPISTÊMICOS DESCOLONIAIS II) durante o II Seminário Latino-Americano de Estudos em Cultura - SEMLACult em Foz do Iguaçu/PR, Brasil, 2018.

2 (Doutoranda em Estudos Transculturais; Institut d'Étude Transculturels et Transtextuels - IETT, Lyon, France; Programa Multidisciplinar em Cultura e Sociedade - Pós-Cultura, Salvador, Bahia, Brasil; paula.luciano@gmail.com)
} 
Palavras-Chave: Campos epistemológicos; Decolonialidade; Espaços e temporalidades; Estéticas Descoloniais; Movências culturais;

\section{Resumen}

Este ensayo tiene como estructura trazar un panorama de las estéticas decoloniales a través del análisis de las expresiones artísticas que tuvieron como escenario el territorio latinoamericano. Este análisis nos permitirá evidenciar las expresiones y prácticas culturales dentro de su pluralidad y los arquetipos espaciales típicos dentro de su resignificación temporal. La necesidad de creación y búsqueda de nuevos campos epistemológicos traducen el movimiento histórico de los movimientos culturales latinoamericanas y la yuxtaposición de temporalidades, prácticas y la confluencia de conocimientos. Podemos encontrar un escenario de resistencia y de fronteras socio-históricas subvertidas, principalmente en lo que se refiere a la realización de manifestaciones artísticas y culturales y su capacidad de invención y relativización. Este ensayo tiene por objetivos traer una reflexión sobre la construcción de espacios culturales y la deconstrucción de una mirada única y dominante para definir las prácticas artísticas. El análisis y el cuestionamiento epistemológico del movimiento trans-histórico latinoamericano dibujan un panorama de la historia de las producciones artísticas provenientes de prácticas e invenciones de la vida cotidiana y de la elaboración de espacios temporales de reivindicación y contestación a partir de exposiciones, performances, festivales, etc. La idea de subvertir un imaginario geopolítico y un orden cartográfico del mundo (aunque inicialmente a partir de dinámicas locales) consiste en un punto central de ese trabajo.

Palabras claves: Campos Epistemológicos; Decolonialidad; Espacios y temporalidades; Estéticas Decoloniales; Movimientos Culturales

\section{Introduction}

This essay on Decolonial Aesthetics in Latin America consists of a work under construction and in development of ideas. It focuses mainly on the ideas of the Global South Biennials and, eventually, the process of 'biennialization' throughout the art world events. The first part takes the ideas of Decolonial Aesthetics as a dialectal process and it develops variant dimensions of thoughts in order to take the studies from an event to a broader understanding of culture. These dimensions of comprehension can be enumerated as: conceptual, epistemological, territorial, relational in terms of time and space, cultural, and the movement, the mouvance that crisscrosses social relations.

The second part of this essay will venture in the realms of the Third Havana Bienale in order to give a deeper look into the curatorial processes and choices that were taken during its formulations. Also, towards an understanding of how it was one the basis to Biennials of the so-called 'Third World' as it is meant to question the Eurocentric devolving of worldly events of Biennials of art. The thoughts and analysis concerning the Third Bahia Bienale are under construction and the third part of this essay functions as an introductory index for further writings and thoughts. Lastly, but not least, we will begin to understand the idea of Latin America not as a geopolitical frontier, but as a trans-historical cultural movement. 


\section{Dialectics of the Decolonial Aesthetics}

The disposition to discuss the dialects of decolonial aesthetics suggests more than a definition of a concept devoid of context, it requires at least an attempt to comprehend the cultural standpoints to which it responded and the effects of its upheaval to academic purposes. Even though, sometimes, I have a certain impression to be able to locate the usages of the term in non-historical dialects. It could be, perhaps, because of one's inclination to turn concepts into a universal strategy, despite the tendency, in the case of the decolonial aesthetics, to be constantly written and taken to a 'pluriversal' dimension. In a sense, to englobe 'pluriversal' dimensions to a concept pretty much synthetize it to a global dimension entirely. The shift, notwithstanding, consists in understanding the meaning of turning a concept into universal, on one hand, and to assume that universal thoughts are entitled to be acquired by every acknowledged perspective, on the other hand. Inasmuch the local can also be universal. Or, furthermore, every local can be universal. Therefore, the multiplicity of local universalities consists of dynamic mindsets in co-existence. Correspondingly, palimpsests hold idiosyncratic plurality.

The term 'pluriversal' was coined by semiotic researcher Walter Mignolo when discussing about "pluritopical hermeneutics" (MIGNOLO, 2013). According to him, hermeneutics refers to a reflection on meaning within a single cosmology. Whereas while studying hermeneutics among more than one cosmology, the necessity to pluralize the concept is essential not to dismantle or exclude any referred meaning. Moreover, he idealizes 'pluriversality as a universal project' within the decolonial option in order to des-hierarchize the hegemony of believed universal concepts by Western thought and the challenge to enlarge the acknowledgement of epistemic configurations (Idem, 2000).

The non-historical character of the decolonial aesthetics above referred functions in the sense that through this perspective not only artistic expressions are thought and created, but it has equally the dynamics of observation, research and englobing artistic expressions that were created in different temporalities and places in relation to when and where the concept was coined. For instance, decolonial aesthetics, beyond the conceptual limitations, consists in learning "ways of looking". Even the artistic expressions that were not thought through the lenses of decolonial aesthetics can be looked at under that perspective. It could differ from Western concepts that are turn into universal when the decolonial aesthetics lenses open a perspective of "looking" and start measuring a myriad of artistic manifestations into 
being or having certain specificities that fit a major movement, that of the decolonial sciences. As for the Western thought, it has constructed universal concepts to function as parameters of development, progress, growth, and advancement.

The decolonial science is often talked about as being an Option, instead of a theory. An option of looking, of analyzing, of being, of existence, of searching for more local coherent ways of expressions and cultural manifestations, and so forth. In a way, to take decolonial aesthetics as an option represents a constant reflection about the reality in which people live, about the every-day life contingencies, about social construction, and, thoroughly, it is also about self-utterances. In conjunction with that, the decolonial aesthetics leads a movement that aspires to liberate the senses and sensibilities out of Western categories, artistic ranks, art markets, and individualized artist's awards. The initial task, which means that to "identificar la lógica de la colonialidad en cada una y en las relaciones es en símismo un trabajo descolonial"3 (CARBALLO, MIGNOLO, 2015), indicates that we engage in an on-going task to reach consciousness of relations of power and dominance in order to eventually dismantle them. Notwithstanding, we engage in identifying this logic in terms of the theoretical realms of the aesthetics. To liberate aesthetics means to liberate sensations, process of perception, hearing and tasting sensations.

Indeed, to have been studying and discussing the decolonial aesthetics spectrum of analytical looking, it has provided some sort of tickle that triggers every now and then when coming across artistic expressions. This tickle corresponds, beforehand, to growing an affection towards the untranslatable perception of belonging. It seems that it accompanies the analytical processes of decolonial aesthetics. In the same manner, it happened when I first came across the exhibitions within the Third Bahia Biennial. It tickled a trigger of amusement, not because I had exactly what I needed to know about that event, but because there was a disruption and a whisper of construction that subverted a logic of looking and sensing that I had internalized in my brain. Instead, what exactly I had to feel or sense meant to, eventually, arise within the dialects of the event, the catalogues, the publications and the memory of people who had been involved somehow. In some cases, maybe listening come forward with ways of looking. It gives an impression of placement intertwine with voice-

\footnotetext{
3 "to identify the logic of coloniality in each one and in each relation consists in itself a decolonial task" (our translation)
} 
fiction. Placement, instead of displacement in order to forge a territorial connection. Voicefiction, instead of the ethnological writing in order to disarray the zones of silence.

Most of the time, I stumble to simply identify in my work, in my writings that an event or an expression corresponds to an aesthetics that is decolonial without having a permit to move forward and deeper into their cultural studies and analysis. I also question if we are able to look and perceive as decolonial artistic expressions whose creators or artists do not call it the same way. What would be our role as intellectuals within the decolonial project? In my perspective, it would start with becoming aware and to act into awareness. The crucial point dwells in keeping the reflection and the construction into possibilities of looking.

Anyhow, the term decolonial aesthetics emerged out of a manifesto composed in 2011 by mainly Latin American intellectuals, artists, curators, researchers who had been engaging on the conceptual dimensions of the coloniality/decoloniality/modernity working group. The active claims of decolonial aesthetics have been discoursed in general terms at the Transnational Decolonial Institute. For instance, one of the counterclaims can be read at the manifesto bellow.

\footnotetext{
Within different genealogies of re-existence 'artists' have been questioning the role and the name that have been assigned to them. They are aware of the confinement that Euro-centered concepts of arts and aesthetics have imposed on them. They have engaged in transnational identities-in-politics, revamping identities that have been discredited in modern systems of classification and their invention of racial, sexual, national, linguistic, religious and economic hierarchies. They have removed the veil from the hidden histories of colonialism and have rearticulated these narratives in some spaces of modernity such as the white cube and its affiliated branches. They are dwelling in the borders, sensing in the borders, doing in the borders, they have been the propellers of decolonial transmodern thinking and aesthetics. (Decolonial Aesthetics (I) Manifesto. Sunday, May $2^{\text {nd }}, 2011$ )
}

When referring to different genealogies of re-existence, what comes to mind is the assemble of relational dimensions within heterogeneous cosmologies. Professor Robbie Shilliam reflects on the aspects of genealogies and different cosmologies by addressing "multiplicity as deep relation rather than categorical segregation" (SHILLIAM, 2015). Deep relations with ancestrality, with the land, with spirituality, with visual elements expressed within different cosmologies, and, above all, deep relations with each other. That is to say that the relational aspect of the decolonial aesthetics must encounter space to flow, must become indispensable to create bonds that are disconnected with power relations within artistic 
expressions. Another important extract of the statement above refers to the engagement of transnational identities-in-politics. That is to say, the identities that emerged inside of the nation-state formations world-wide reflects the identities that mirrors historical dominance among the subjects subjugated throughout colonization. Therefore, an identity that is restored by means of covering former power relations must reveal exact the standpoint of where memory should come at stake. Identity-in-politics pinpoints the fact that these identities created out of modernity enclosed by the realms of capitalism should be understood inwards a political system, namely, the political system of the Nation-State and the dictation of representation. The conflict between the identity-in-politics contraposing the identity that comes out the genealogy of memory finds its mid-term at the border or the frontiers. The production of border subjectivity crisscrosses an important catalyst among artists, curators, filmmakers, intellectuals, professors engaged in the discussions of the decolonial sciences. It represents the 'set in motion', the impetus to think and act not outside, as to say in peripheral or marginalized spectrums of cultural, but to comprehend that an identity-in-politics escapes its essentialism and dwells above and beyond the labyrinths of Western geopolitical relations. Deep-seated in this labyrinth, there lies the "fabrication of meaning and interpretation" (DUSSEL, 2011) that interpellates world orders and dismantle social continuities.

In the interests of border thinking, as stated by intellectual Glória Anzáldua, we need to reflect on the concept of frontiers in the first place (ANZÁLDUA, 1987). It refers to learning how to place one's self within the epistemological frontiers of thinking and to recognizing knowledge that is officially absent and engage them into the cultural mouvance that are intelligible to each local or translocal reality (ZUMTHOR, 1972). "El pensamiento fronterizo, la estética fronteriza, la sensibilidad fronteriza, la política fronteriza, la economía fronteriza (...) son parte del pensar y hacer descolonial” (CARBALLO, MIGNOLO, 2015), this statement rectifies the complexity even to reflect on the decolonial activities through the notion of frontiers and the displaced subjects.

If we think of borders as struggles, then we need to think about the epistemological border between reality and representation (MEZZADRA, NEILSON, 2013). The latter consisting of the national political recognition of representation through state jurisdiction; and the former consisting of the flow and the contingency of the border, that is to say that inasmuch the border functions as a capture, it in the passage of the struggle that the identity conflict enters in contradiction. Therefore, to dwell in the border means to be in constant flow, movement, reinvention of social relations, reconnection with different sources of knowledge, 
to be in dialectal zones of contact, where spaces of perceptions can be forged, and where culture meets its transnational ingenuity. We must acknowledge the border not only as a geopolitical demarcation, but also to bring the notion of border to the center of governance (Idem, Ibidem, p.8). Border is management, on one hand. And border is transgression, on the other hand. Decolonial sciences finds the border flaws through its blind spots. If the struggles, when dwelling in the borders, are submitted to confronting state representation and power relations, then there is a symbolic construction by the activities within the borders that are related to reinvention and to forged spaces of movement, creativity and flow.

What does it mean then for the decolonial aesthetics the notion of dwelling in the borders? To the extent of comprehending its process of functioning, artist and intellectual Pedro Pablo Gómez states that

las prácticas estéticas descoloniales no se realizan en una exterioridad absoluta al sistema - mundo moderno colonial - sino en su interior mismo, en sus márgenes e intersticios, en las marcas no cicatrizadas, heridas causadas por la acción colonial, tanto en los mapas del mundo como en los cuerpos de las personas y las formas de vida en las que esos mapas y marcas fueran y siguen siendo inscritos. ${ }^{4}$ (GÓMEZ, MIGNOLO, 2012, p.16)

Moving towards the imaginaries of border thoughts and struggles assembled through the decolonial aesthetics lenses, the Western relation of time and space disguises the interstices of memory by not recognizing it thoroughly. Therefore, it is indispensable to reflect on the relations time and space and to dismantle the notions of documentation, archives, memory that quantify them. We can think of time as relational and in constant modification; and the space as palimpsest traces, that can be erased and written upon. Professor Rolando Vázquez argues that the decolonial aesthetics works to transgress the dominance of space as the original center of relations (2016). Whether we think of aesthesis as a process of creation, perception and sensation then it allows to juxtapose the symbolic dimension of life with the everyday life struggles that are connected to state representation of social construction. This dimension of interweave annihilates the Western notion of chronological time and space demarcation by creating the possibility of other imaginaries

\footnotetext{
4 "the decolonial aesthetics practices are not active in absolute exteriority to the system - the modern colonial world - but in its interior, in its margins and interstices, in its non-healed scars, in its bruises caused by colonial action, in the maps of the world and the bodies of the people and the ways of life in which these maps and scars have been and still are registered." (our translation)
} 
devoid of institutional agreement or imposition. To manifest different imaginaries of time and space through cultural and artistic expressions releases full dependence on state regulation and representation whereas it redirects the perception to a new focus of struggle and its claims to exist.

Under the circumstances, decolonial aesthetics does not operates through artistic creations of form, Kant's notion of beauty, the capitalist's art markets, or representing images of genealogic nobility unparalleled with other broader dimensions of social relations and thoughts. Therefore, decolonial aesthetics inquiries dimensions of: conceptualization, epistemology, territory, relations of time and space, cultural, and the movement, the mouvance that crisscrosses social relations.

The conceptual dimension consists of investigating and contesting accepted structures of knowledge. For instance, the question is not in identifying what is Latin American, but when Latin American happened (LEE, 2010). It stands for the moment to question the instituted geopolitical imaginaries by identifying: socio-historical displaced, detached, juxtaposed, and crossed frontiers through boundaries determined by the systems of domination and repression (CASTORIADIS, 1997). It also stands in the acknowledgment of expressions - such as territorial, symbolic, spiritual, artistic, cultural - inherited from cultures with evanescent structures that were disrupted due imposed instability.

The epistemological dimension refers to the production of knowledge not only within institutional establishments, such as the universities, museums or research centers, but also through the knowledge that is produced in contexts of disrupted of formations subjectivities. The weaving of transnational bonds that functions in heterogeneous communal logics, instead of national rationality. Moreover, the epistemological inquires to translate the trans-historical movement of the cultural mouvance, the juxtaposition of temporalities and the confluence of knowledges.

The territorial dimension questions the formation of geopolitical territories, meaning the implication of Nation-states as being the endorsed parameters of relational societies. For instance, the Berlin Conference in 1855 when the world was configured by hegemonic European countries; and a hundred years later the antithesis Bandung Conference when nearly independent countries encountered to oppose colonialism and neocolonialism and the attempt to promote cultural cooperation among the members. Another dimension of the territory refers to the internal divisions inside of the realms of the Nation-state. For example, the 
Northeast region of Brazil, where the city of Salvador is located and where the Third Bahia Biennial took place assembles, through the symbolic dimension of its nomos, a national representation and processes of subjectification that arises from it. Professor Durval Muniz argues that the Northeast is an invention or an emergence (2011). It dialogues with the conceptual dimensions mentioned above.

The relations of time and space discusses temporal archetypes of cultural construction. It leads to perceptions of time and the re-signification of temporalities, otherwise saying, the relational time that assumes plural temporalities. Therefore, time emerges as a presence within spatial determination. The theory of coeval-ness, or the denial of it, holds the possibility of accepting that different temporalities can co-exist within the same shared space without overlapping. The notion of 'denial of coevalness' was developed by Johannes Fabian in his work entitled Time and the Other - How Anthropology Makes its own Object (1983).

And the cultural dimensions of decolonial aesthetics stands for the thesis of studying the notions of culture considering its many layers of comprehension. One of the tasks, from which I will lean this work, consists in analyzing and questioning the trans-historical movements that are subjacent to the cultural-artistic manifestations of practices, and the recurrent reinventions of the every-day life that elaborates temporary spaces of claim and contestation by means of: exhibitions, performances, festivals, biennials, triennials, originating reenactment celebrations; and so forth. Moreover, to recognize within the temporal-spatial conjunctions, the assemblage of cultural and artistic demonstrations of sociopolitical mouvance that are precedent of pluriversal, transnational and trans-historical cosmo perspectives.

The inquiries of this trans-historical movement draws a paradigm of the history of: (a) territorial disputes; (b) the negotiation of frontiers within the national institutions, such as the museums; (c) the cultural mouvance that escapes the scope of state legitimation; (d) the construction of national geopolitical borders of hierarchy; (e) the official epistemology of Westernized models. Therefore, by taking the Third Bahia Biennial as a study case under construction, these questions above mentioned are aimed to be recognized and, eventually, subverted. Not only in the sense of exposing the artistic expressions that composed the catalogues and the curatorial choices of the event, but also in the realms of the analytical cultural studies spectrum of working on the search for contradictions, constraints and commands. But first of all, we will take a look on the beginnings of the Havana Biennials, 
specially the Third edition. This analytical choice has to do with the fact that the Bahia Biennial acknowledged it as a matter of reference. In addition, when dedicating a deeper look into the Havana Biennial, we can also draw the attention to certain specificities that will assist us in understanding different curatorial perspectives.

\subsection{The Third Havana Bienale}

The Biennial of Havana has told a different story from the stories told by internationals biennials elsewhere in the world. So it has described the professor and art administrator Rachel Weiss and many other cultural agents who had the opportunity to stand by the long term Biennials held at the Centro de Arte Contemporánea de Wifredo Lam in Cuba (WEISS, 2011). As a consequences of the Cuban Cultural Revolution in 1959, the Lam Center was founded in 1983 as part of the cultural policies being applied to the country under the administration of the Minister of Culture Armando Hart Dávalos - active from 1976 to $2003-$

The cultural center is named after Wifred Lam, which is one of the modernist/surrealist/cubist artist who had just died one year before, in 1982. Lam was known by being a "tri-continental" artist, which translated the transcultural movement of African and Asian diasporas departed to a Latin American country. Lam used to say that 'mi pintura es un acto de descolonización'5 (In ROJAS-SOTELO, 2009). Indeed, his paintings and drawings did not follow necessarily conservative techniques of the European art aesthetics of his years. Not to mention that Cuba was not any country whatsoever for which it represented the communist stand of the Americas. Aligned with the Soviet Union, against the United States upcoming imperialism and under the Marxist state intervention ideals, the national command was taken by Fidel Castro after the Revolution. He, who remained in power as a Prime Minister from 1959 until 1976 and then as President from 1976 till 2008, also put his signature to asserting the creation of the Lam cultural center, under the direction of art historian Llilian Llanes.

With the intellectual movement working activities, Havana held the World Congress of Culture in 1968. One of the purposes of the congress leaned on discussing the cultural issues of, how it was known at the time, Third World countries. Afterwards known as the Global South. The general theme concerned mainly 'Colonialism and Neo-colonialism in the

\footnotetext{
5 "My paintings are an act of decolonization" (our translation),
} 
Cultural Development of Peoples ${ }^{\prime 6}$. The discussions, therefore, led the movement to a social and intellectual upheaval that structured, as a consequence, the character of artistic and cultural manifestations promoted by the Center. "El movimiento de pensamiento crítico" was the name of that intellectual movement ${ }^{7}$. The processes of national independence in Central and South America transposed, likewise, the transfiguration of a colonial process, gradually turning from a colonial imaginary to its dismantling into different struggles exact through the dimension that framed the role and focus of most intellectual claims.

A year after its creation, the $1^{\text {st }}$ Biennial of Havana took place at the Lam cultural center. The project was co-founded by Nelson Herrera Ysla and Gerardo Mosquera. It was also intentional that this Biennial carried the "tri-continental" decolonial move under a curatorial and scholarly collective practice. According to Herrera it was important to locate themselves in the universe of artistic practice (In ROJAS-SOTELO, 2011). What had been functioning as a two-way manifold of paradoxical manufacturing of art events, the biennials established a currency of forged visibility, integration and territory to be contemplated with social and cultural which content was conventionally unattached. It was not merely only a matter of artistic aesthetics and form anymore, but how art inherently developed in direct dialogue with the internalized ethno-cultural acknowledgements of local contexts.

The $2^{\text {nd }}$ Biennial, in 1986, reached out its former edition to slide on the prospects of European-based artistic events - very early practice initiated through the format of Salon des Arts in patrician rooms in $18^{\text {th }}$ century Paris flourishing with the groundworks of modernity and taking variant configurations henceforth (HALL, GIEBEN, 1993) - on one hand, and, on the other hand, it reached out to a different demands shared by an artistic global movement living on intellectual and social displacements. Whereupon, the biennial intended to "emphasize the use of the city. It was not to be an exhibit but a mosaic of exhibitions" (CAMNITZER, 2009, p.215). A mosaic would allow, in that case, to amplify the visualities that were outside of museum walls, outside of the standard portrays, and outside a solely concept of art.

Thriving to the $3^{\text {rd }}$ Biennial of Havana, the initial break in pattern was in respect of the literal meaning of a biennial, that is to say, that occurs every two years. It seems as a

\footnotetext{
${ }^{6}$ Papers from the Cultural Congress of Havana, date range 1967-1968.

https://www.georgepadmoreinstitute.org/collection/papers-cultural-congress-havana. Consulted on May, 2019.

${ }^{7}$ Critical Thought Movement (our translation).
} 
concurrent misleading gesture of hosting biennial events within countries of displaced and disposed cosmologies. In practice, it connects usually with political and economic situations; in philosophy, perhaps, it connects to a different perception of time in the clashing mindsets. Only one tardy year, therefore, in 1989, the Lam center held its $3^{\text {rd }}$ Biennial edition. Assuming indeed curatorial changes in organization and practice that, eventually, registered Havana in the spotlight of artistic events within the Global South. Including the consolidation of a Cuban art market. Mosquera's dialectics to describe their consent to consciously distance Latin American art to Eurocentric standards reports that "If we are to be marginalized, let us create our own space, our own networks, values, and episteme and project them to the world" (MOSQUERA, cited in BRUCE, 2018).

Although very much attached to a world dynamics and Eurocentric art-historical paradigms, the Biennials of Havana crisscrossed the central conservative institution in order to conspicuously create imaginaries that distance from hegemonic aspirations of art. In a way, it functions as a measure of time and space. For instance, what is produced in Latin America cannot reach out for worldly hegemonic art critique, not because incapability or inferiority due under developed ideas of progress, however necessarily due different connections linked to the every-day contexts and the possibility to make sense out of its own reality. Pinpointing manifestations as precarious or unscrupulous might be a stand to back off conventional curating critics to pull a rank out of unsettled artistic hallmarks. Nonetheless, the aesthetics of precariousness ended up by suiting another capitalist intervention to redefine and refine the offspring of cultural manifestations in Latin American contexts. For instance, artist and intellectual Luis Camnitzer establishes an analogy between ANIR (National Association of Innovators and Rationalizers, acting since 1976) and the state-of-the-art peripheral artists. The ANIR is based on "cannibalizing parts, recycling them, and using a redesigned philosophy" gathering scientists and technicians to use ingenuity to solve technological problem (2009, p.70). The bricolage aesthetics, as he points it. The analogy arises to use this technical strategy as a metaphor for the "use of ingenuity on the periphery and for a true aesthetic of poverty" (Idem, Ibidem, p.71). On the other hand, the usage of coherence to turn artistic expressions intelligible to a Third World context seems to overstep the exacerbations of selfproclaims to institutionalize an opposite direction of the accepted standards.

"Tradition \& Contemporaneity" were points at issue during the Third Havana Biennial. Almost an exponential growing paradox to make ends meet. The term tradition hereby does not only imply the continuity of techniques and vogue within the artistic practices 
and creations, it conforms an on-going and more profound socio-cultural process that concerns collective subjectification of memories into local traditional patterns. It connects to a deeper range of cultural stratifications, such as religion, rituals, and ceremonies. Mainly philosophical inquiries that has been partially dispensed compared to the practices of what is called the contemporary production of art. Everything for the sake of form and beauty. The aesthetics of minimalist tech-science. And the term contemporary collaborates to open possible layers to define art into and within spectrums of what the Western thoughts externalized as anthropological, popular, diasporic, and cultural expressions. The "spectrum of multiplicities" (BRUCE, 2018, p.33). Fragmented. The instability of the definition of 'contemporaneity', mainly due the fact that we define as we move and we also change while moving, responds, therefore, to an investigation into this multiplicity of voices. Curator Gerardo Mosquera believes that the centralization of art systems functions outwardly to "keeping disconnected the zones of silence" (1999, p.134). For that matter, there must be a shift of perspectives. The investigation should achieve a different level of comprehension where it does not include practices by an anthropological force, but the investigation achieves an opening into the system by creating a disruption of pattern. A crack to forge an entrance and register other practices into contemporaneity.

The second step taken within the Biennial concerns a curatorial decision to remove jury awards and prize-winning competitions at the end of the event. Somehow, these awards stipulate criteria based on the already hegemonic standards of world art evolution. As reported by the Lam center director Llanes, it is more precious "to turn its energy towards the dialectical, tense and problematic relationship between "tradition and contemporaneity" then to fabricate a competitive dimension inside the event (Cited in ROJAS-SOTELO, 2009, p.239). Nevertheless, how to honor divergent artistic practices and art languages which dialectical context clashes? This interrogation samples Ibis Hernandez' forum where it questions the defense of a contemporary art to the Third World (Idem, Ibidem, p.140). The range of art works displayed at the Biennial accessed a great amount of cultural horizons. There were artists such as Oioguibi Fanabe from Nigeria who worked as a 'ibogolan”, which defines an artist who "drives ancestral and contemporary images and practices" (Idem, Ibidem) into their work. Or the photography portrays by Sebastião Salgado overviewing Brazilian gold mine workers. Or the extremely manufactured Chinese kites. Or even art works by artist Luis Camnitzer's international conceptualism. Or Tinga Tinga school of paintings in Kinshasa. Or Manuel Mendive's installation objects "La Luz" which were derived from 
Yoruba rituals as part of the Santeria tradition. Or the carnival masks from Guinea Bissau. Or the Vietnamese Dang Xuan Hoa's romantic modern abstraction. Or the Philippine crew composed by Santiago Bose, Raymond Maliwat and Roberto Feleo - who "addressed mythical forms, materials, and colors, relating them to local political struggles" (ROJASSOTELO, 2009, p.249). Or Juraci Dórea's "Project Earth" photo installations. Or, even, toys, masks and assemblages from several African countries. Only to name a few of the artists. How would have been possible to honor them all for their own craftsmanship? How would have been possible to look at them all and not categorize them? How would have been possible not to hierarchize each and every one of these artistic manifestations?

The concerns that goes beyond the purely critique of art lead aesthetics essentialisms to an utterly revitalization of its concepts and criteria to displaced artistic encounters. As a matter of fact, some Biennials of the Global South tend to teach about and lean "towards more horizontal axes of dialogue and engagement across a region-promoted as transcultural and communal" (GARDNER, GREEN, 2016, p.92). In any way, some exhibited artworks mentioned above cannot be disassociated or distinguished to the collective manners in which they were created. This indicates that the liability of authorship fails to include the sociohistorical and cultural process as interdependent. The engagement on transculturality whatsoever requires a deeper analytical stand point to every national formation in order to find out that any definitive definition on culture, local or national, is a downfall.

To follow up, the third step walks into the curatorial and research procedures adopted throughout the organization and the exhibitions. Unlike the $1^{\text {st }}$ and the $2^{\text {nd }}$ editions, the third Havana Biennial approached research processes delinking from Western curatorial maneuver. The method adopted to curate artists endorsed an anthropological research based on observant-participant criterion. On Mosquera's perspective, there are usually a "curating culture" and "curated cultures" (1994, p.135), which means that the curated cultures invited are devoid of collaborative intervention of their own works. The complexity of each of these contexts happen to be displaced into shared zones of contemplation or geopolitical assemblages. Sometimes it makes sense. Sometimes it does not intertwine properly. The praxis come with the work.

In order to illustrate Mosquera's statement, we can take a quick look at the curatorial process of the exhibition named Les Magicians de la Terre, coincidently exhibited in that same year of 1989 at the Pompidou Center in Paris. In a way, curator Jean-Hubert Martin was 
determined to contrapose the 1931 's exhibition L'Exposition Colonial, in the $12^{\text {th }}$ arrondissement in Paris at the bois de Vincennes where the Palais de la Porte Dorée was constructed for the occasion. The international colonial exhibition represented a museum of the colonies, therefore, gathering the assemble of French possessions captured during the colonial period. It portrayed territories, the history of each colony conquest, and the impact it has had within the art dimension ${ }^{8}$. Subsequently to the Cabinet de Curiosité, the International Colonial Exhibition represents the first signs of the creation of the anthropological (or folkloric, or ethnological, or popular) museums. Anyhow, Les Magiciens de la Terre hosted more than a hundred artists supposedly equally invited from Euro-American and non-Western countries. According to the article by art writer Sean O'Toole to Frieze Magazine, "The exhibition was non-hierarchical in the sense that it juxtaposed established artists (...) with a broad constit-uency of non-Western folk artists, crafters, shamans, priests and hard-to-classify visionaries" (2017).

Therefore, the act of assembling artworks from all over the world consisted in Martin's attempt to demonstrate that art can be practiced elsewhere outside Euro-American art galleries and the criteria to define art was not necessarily reliable. However, to call "magical" or to mention "magicians" in order to connote non-Western art and artists reinforces the assumptions that Mosquero argued as the notions of "curating and curated cultures”. Camnitzer's critique of Les Magiciens de la Terre conveyed that:

the mega-exhibition addressed and brought 'otherness' to the mainstream of contemporary art becoming also a place to define the 'other' instead of allowing it to identify and define itself without the orchestration of fancy institution and big budgets. (Cited in ROJAS-SOTELO, 2009, p.248)

The notion of otherness does not include the guarantee of qualitative dialectical response to its contextualization, nor it underlies Euro-American artistic productions to its own historical transcultural movement. The curatorial process of the Third Havana Biennial accepted and assumed the epistemic challenge to contest a know-how on curating big events of art. Perhaps, the notion of 'otherness' in this context arose to an opposite direction, since Euro-American artists were barely considered to be invited to participate.

The line between how anthropology works on art curating can be quite still subtle. For the fact that the realms of anthropological consent do not support National-based identities, or

\footnotetext{
8 "L'Exposition coloniale de 1931"

http://www.palais-portedoree.fr/fr/decouvrir-le-palais. Consulted on May, 2019.
} 
else, the identity-in-politics. On the opposite, the realms of anthropological consent bear the contradictions within every nation's constitution. That is to say, the discussions on "tradition and contemporaneity" within the Third Havana Biennial are inconclusive crossroads, because the definition of each of those terms might essentialize them. It is the dialectical construction of these concepts that develops its own particular praxis whereas these formulations on curatorial processes will work to the extant to build one of the bases for the Third Bahia Biennial which holds its own national and regional contradictions and imaginaries.

\title{
2.2. The Third Bahia Bienale
}

Curators Gerardo Mosquera was interviewed by Liane Heckert to the Revista Contorno, a journal that was developed to explain the curatorial and contextual processes of development of the Third Bahia Biennial. In the interview, that was named "For an inverted gravity", Mosquera states that one of the possible parallels that we can draw among the first Havana Bienales and the Bahia Bienales

\begin{abstract}
is when they choose to position themselves in a context so from where they can measure the world and act on it. They are projects that invert the power equation, that don't think of the Northeast or the entire Third World within a local spirit, but inside of a universalizing wish to create new spaces for proposals and encounters, actively pluralizing the international ecology of art. (HECKERT, MOSQUERA, 2014, p.90)
\end{abstract}

Indeed, since its first edition, the Bahia Biennials means to have a contextual position - which is importantly geopolitical, socio-cultural and trans-historical - to functions as a bottom line of understanding its own perspectives. The $1^{\text {st }}$ and the $2^{\text {nd }}$ Bienales are mainly contraposing the artistic expressions of the Southeast. Since the Week of Modern Art (1922), the Southeast appropriates alone of the definition of what constitute national art. Therefore, due the fact that the Biennial of São Paulo curatorial processes usually operates in functioning also as a determinant of national art, the first Bahian Bienales worked on dismantling this national idea of art by constructing a different perspective on artistic expressions with local artists and telling a different story.

The Third Bahia Bienale dissolves the worldly constituted notion of Biennials by changing the curatorial development of exhibitions, decentralizing the places of occurrence, taking the event to cities that usually does not receive art events of large scale, opening spaces of dialogue with the urban social and cultural surroundings, and functioning as a catalyzer inasmuch as a journey. 


\section{Referências}

ALBUQUERQUE JÚNIOR, Durval Muniz. A Invenção do Nordeste e outras artes. São Paulo: Editora Cortez, 2011.

ANZÁLDUA, Gloria. Borderlands: the new mestiza - La Frontera. São Francisco: Aunt Lute Book Company, 1987.

BRUCE, Amy. "International Contemporaneity and the Third Havana Biennial (1989)". RACAR: Revue d'Art Canadienne 43, No 2, 2018, pp.25-33.

CAMNITZER, Luis. On Art, Artists, Latin American, and other Utopias. Austin: University of Texas Press, 2009.

CARBALLO, Francisco. MIGNOLO, Walter (Org.). Habitar la Frontera. Sentir y pensar la descolonialidad (Antología, 1999-2004). Barcelona: CIDOB y UACI, 2015.

DUSSEL, Enrique. "From Critical Theory to the Philosophy of Liberation: some themes for dialogue", Transmodernity: Journal of Peripheral Cultural Production of the Luso-Hispanic World, Fall 2011. https://escholarship.org/uc/item/59m869d2\#main. Consulted on May, 2019.

FABIAN, Johannes. Time and the Other - How Anthropology make its own objetc. New York : Columbia University Press, 1983.

GARDNER, Anthony. GREEN, Charles. Biennials, Triennials and Documenta: The Exhibitions that created Contemporary Art. New Jersey: Wiley-Blackwell, 2016.

GÓMEZ, Pedro Pablo. MIGNOLO, Walter. Estéticas Decoloniales. Bogotá: Universidad Distrital Francisco José Caldas, 2012.

HALL, Stuart. GIEBEN, Bram. The Formations of Modernity: Understanding Modern Societies. New Jersey: Wiley, 1993.

HECKERT, Liane. MOSQUERA, Gerardo. "For an Inverted Gravity". Salvador: MAM-BA, Revista Contorno 04, 2014, pp.90-92.

LEE, Gregory. "If America Were Really China or How Christopher Columbus Discovered Asia", in Rethinking American Studies - Media, Languages and Geographies, National Library of Sweden, 2010.

MEZZADRA, Sandro. NEILSON, Brett. Border as Method, Or, the Multiplication of Labour. Durham: Duke University Press Books, 2013.

MIGNOLO, Walter. Local Histories/Global Designs - Coloniality, Subaltern Knowledges, and Border Thinking. New Jersey: Princeton University Press, 2000.

."On Pluriversality", Posted on October $20^{\text {th }}, 2013$. http://waltermignolo.com/onpluriversality/. Consulted on May, 2019.

MOSQUERA, Gerardo. "Some Problems in Transcultural Curating", In FISHER, Jean (Ed.). Global Visions towards a new internationalism in the visual arts. London: Kala Press, 1994. 
O’TOOLE, Sean. "Other Stories", Frieze, Issue 6, October 1, 2017. https://frieze.com/article/other-stories. Consulted on May, 2019.

ROJAS-SOTELO, Miguel. "Cultural Maps, Networks and Flows: The History and Impact of the Havana Biennale 1984 to the present", Thesis dissertation submitted to the Faculty of History of Art and Architecture of the University of Pittsburgh, 2009.

. "The Other Network: The Havana Biennale and the Global South". Indiana University Press, The Global South, Vol. 5, No 1, 2011, pp. 153-174. Project MUSE: https://muse.jhu.edu/article/449223 Consulted on May, 2019.

SHILlIAM, Robbie. The Black Pacific - Anti-Colonial Struggles and Oceanic Connections. London: Bloomsbury Academic, 2015.

WEISS, Rachel. To and From Utopia in the New Cuban Art. Minneapolis: University of Minnesota Press, 2011.

VÁZQUEZ, Rolando. CONTRERAS, Miriam Barreras. "Aesthesis Decolonial y los tiempos relacionales: Entrevista a Rolando Vázquez”, Calle 14 - Revista de Investigación en el campo del arte, Vol.11, No.16, 2016, pp.76-93. https://dialnet.unirioja.es/servlet/articulo?codigo=5687728. Consulted on May, 2019.

ZUMTHOR, Paul. Essai de Poétique Medievale. Paris: Seuil, 1972. 